Article

\title{
Column Leaching of Greek Low-Grade Limonitic Laterites
}

\author{
Kostas Komnitsas * (iD), Evangelos Petrakis, Olga Pantelaki and Anna Kritikaki \\ Technical University of Crete, School of Mineral Resources Engineering, University Campus, Kounoupidiana, \\ 73100 Chania, Greece; vpetraki@mred.tuc.gr (E.P.); olgapan@mred.tuc.gr (O.P.); akritik@mred.tuc.gr (A.K.) \\ * Correspondence: komni@mred.tuc.gr; Tel.: +30-28210-37686
}

Received: 15 July 2018; Accepted: 29 August 2018; Published: 31 August 2018

\begin{abstract}
In this study, column leaching experiments were carried out to investigate the extraction of $\mathrm{Ni}$ and $\mathrm{Co}$ from low-grade limonitic laterites from Agios Ioannis mines in central Greece. Tests were carried out in laboratory Plexiglas columns using $\mathrm{H}_{2} \mathrm{SO}_{4}$ as leaching solution. Parameters determining the efficiency of the process, i.e., acid concentration $(0.5 \mathrm{M}$ or $1.5 \mathrm{M})$ and addition of 20 or $30 \mathrm{~g} / \mathrm{L}$ of sodium sulfite $\left(\mathrm{Na}_{2} \mathrm{SO}_{3}\right)$ in the leaching solution, were also studied. Upflow transport of the leaching solution with the use of peristaltic pumps was carried out, while the pregnant leach solution (PLS) was recycled several times over the entire test duration. The concentration of $\mathrm{Ni}, \mathrm{Co}, \mathrm{Fe}, \mathrm{Ca}$, $\mathrm{Al}, \mathrm{Mg}$, and $\mathrm{Mn}$ in the PLS was determined by Atomic Absorption Spectroscopy (AAS). The ore and the leaching residues were characterized by different techniques, i.e., $X$-ray fluorescence (XRF), X-ray diffraction (XRD), Fourier transform infrared (FTIR) spectroscopy, and differential scanning calorimetry and thermogravimetry (DSC/TG). The experimental results showed that (i) $\mathrm{Ni}$ and Co extractions increased with the increase of $\mathrm{H}_{2} \mathrm{SO}_{4}$ concentration- $60.2 \% \mathrm{Ni}$ and $59.0 \%$ Co extractions were obtained after 33 days of leaching with $1.5 \mathrm{M} \mathrm{H}_{2} \mathrm{SO}_{4}$; (ii) addition of $20 \mathrm{~g} / \mathrm{L} \mathrm{Na}_{2} \mathrm{SO}_{3}$ in the leaching solution resulted in higher extraction percentages for both metals $(73.5 \%$ for $\mathrm{Ni}$ and $84.1 \%$ for $\mathrm{Co}$, respectively), whereas further increase of $\mathrm{Na}_{2} \mathrm{SO}_{3}$ concentration to $30 \mathrm{~g} / \mathrm{L}$ only marginally affected $\mathrm{Ni}$ and Co extractions; and (iii) when leaching was carried out with $1.5 \mathrm{M} \mathrm{H}_{2} \mathrm{SO}_{4}$ and $20 \mathrm{~g} / \mathrm{L} \mathrm{Na}_{2} \mathrm{SO}_{3}$, its selectivity was improved, as deduced from the ratios $\mathrm{Ni} / \mathrm{Mg}, \mathrm{Ni} / \mathrm{Ca}$ and $\mathrm{Ni} / \mathrm{Al}$ in the PLS; on the other hand, the ratio $\mathrm{Ni} / \mathrm{Fe}$ dropped as a result of the higher Fe extraction compared with that of $\mathrm{Ni}$.
\end{abstract}

Keywords: limonitic laterites; column leaching; sulphuric acid; sodium sulfite

\section{Introduction}

Nickel is the fifth most common element on earth and is widely used in many industrial, transport, aerospace, marine, architectural, military, and consumer applications. Its biggest use is in alloying, particularly with chromium and other metals, to produce stainless and heat-resisting steels [1]. It must also be underlined that nickel is considered today as the most important metal by mass in the Li-ion battery cathodes used by electric vehicle manufacturers [2].

Sulphide ores comprise about $30 \%$ of the global nickel reserves and result in almost $55 \%$ of world metal production [3]. The gradual depletion of high-grade nickel sulphides and the increasing demand for nickel has initiated studies into the exploitation of the huge reserves of nickel laterites [4-6].

It is known that conventional mineral processing techniques cannot be readily applied to laterites due to the complex nature of the ores and the fact that nickel is hosted in several mineral phases $[7,8]$. The treatment of laterites is mainly carried out by pyrometallurgical techniques to produce ferronickel (FeNi) $[9,10]$. However, due to the high capital and operating costs of pyrometallurgy, the use of hydrometallurgical techniques, including atmospheric, heap, and high-pressure acid leaching (HPAL), as well as bioleaching, has gained more interest [11-14]. 
Earlier studies of column leaching indicated that $\mathrm{Ni}$ or Co extraction from laterites is strongly dependent on the type of nickel-bearing phases, leaching time, acid type or concentration, and particle size. In several cases, the use of agglomerating was considered to improve permeability of the reaction bed and accelerate leaching of the useful elements [15]. Duyvesteyn et al. [16] suggested that the ore should be crushed and pelletized with the use of sulphuric acid with a concentration of at least $100 \mathrm{~g} / \mathrm{L}$ to neutralize magnesia. Horizonte, S.G. and Horizonte, D.O. [17] carried out tests in columns with 1 and $4 \mathrm{~m}$ height using agglomerates, concentration of $\mathrm{H}_{2} \mathrm{SO}_{4} 20$ to $200 \mathrm{~g} / \mathrm{L}$, and irrigation rate $10 \mathrm{~L} /\left(\mathrm{m}^{2} \cdot \mathrm{h}\right)$. Their results indicated that higher acidity leads to faster kinetics and recoveries of $84 \%$ for $\mathrm{Ni}$ and 70\% for Co after 150 days of leaching. Elliot et al. [18] performed column leaching tests using various Australian nickel laterites, which were agglomerated with the use of water and sulfuric acid in a rotating drum. The leaching solution contained $200 \mathrm{~g} / \mathrm{L} \mathrm{H}_{2} \mathrm{SO}_{4}$ while no recycling was involved. Depending on the ore mineralogy, extractions of $10-98 \%$ for $\mathrm{Ni}$ and $12-97 \%$ for Co were obtained after 120 days of leaching. The same study indicated that $\mathrm{Ni}$ and Co extractions were increased for laterites containing low goethite and moderate smectite content. Quast et al. [11] studied the behavior of siliceous goethitic ore and the effect of agglomeration on $\mathrm{Ni}$ and Co extractions in column studies, with the use of $\mathrm{H}_{2} \mathrm{SO}_{4}$ for a period of 100 days; also in this case, no recycling of the leaching solution was carried out. The authors mentioned that the feed size influences $\mathrm{Ni}$ and Co extractions which were, for the finest size used, $90 \%$ and $80 \%$, respectively. In the study by Quaicoe et al. [19], column leaching experiments were performed using agglomerates of saprolitic (SAP) and goethitic (G) laterite ores, $200 \mathrm{~g} / \mathrm{L} \mathrm{H}_{2} \mathrm{SO}_{4}$, and an irrigation rate of $8.5 \mathrm{~L} /\left(\mathrm{m}^{2} \cdot \mathrm{h}\right)$. Ni and Co extractions for the $\mathrm{G}$ ore were, after 100 days, $62.7 \%$ and $55.6 \%$, respectively, while for the SAP ore higher extractions of $90.0 \% \mathrm{Ni}$ and $72.8 \%$ Co were obtained. This is due to the fact that serpentine minerals dissolve more rapidly in $\mathrm{H}_{2} \mathrm{SO}_{4}$ compared with the more refractory goethite. Other studies have investigated the potential of $\mathrm{SO}_{2}$ as reductant, also in the presence of $\mathrm{Cu}^{2+}$ ions as catalyst, to accelerate the rate of atmospheric acid leaching of laterites [20-24].

Greek laterite deposits are mainly located in three regions, i.e., Evia island and Lokrida in central Greece and Kastoria in northwestern Greece. Evia and Lokrida deposits are of limonitic type, with high iron and low magnesium content, whereas Kastoria laterites are of saprolitic type with high magnesium and low iron content. Greek laterites have been processed for more than 50 years at the Larco S.A. pyrometallurgical plant at Larymna to produce FeNi containing 18-20\% Ni [25,26]. The hydrometallurgical treatment of these Greek ores, with atmospheric and pressure $\mathrm{H}_{2} \mathrm{SO}_{4}$ leaching, was first studied in the mid-1980s at National Technical University of Athens (Athens, Greece) [27-30]. Later, at the same institution, research efforts were focused on heap leaching [31,32]. The developed approach, through laboratory and pilot studies, involved the use of $\mathrm{H}_{2} \mathrm{SO}_{4}$, purification of the pregnant leach solution (PLS) by chemical precipitation, and, finally, recovery of $\mathrm{Ni}$ and $\mathrm{Co}$ [33]. No further studies to assess the potential of leaching of Greek laterites were then carried out, while in the last years the quality of the ores has gradually dropped. Thus, the aim of this study is to investigate the potential of column leaching for the treatment of low-grade Greek limonitic laterite and also to assess the effect of the addition of $\mathrm{Na}_{2} \mathrm{SO}_{3}$ in the leaching solution on the overall efficiency of leaching.

\section{Materials and Methods}

The ore used in this study $(\sim 50 \mathrm{~kg})$ is a low-grade $(0.58 \mathrm{wt} \% \mathrm{Ni})$ laterite from Agios Ioannis (LAI), Greece, obtained from Larco S.A mines. It was dried and homogenized by the cone and quarter method, and a representative subsample was crushed to minus $16 \mathrm{~mm}$ using a jaw crusher. Chemical and mineralogical analyses of the ore, after pulverization with the use of a FRITSCH-BICO pulverizer (Fritsch, Dresden, Germany), and of the leaching residues, after drying overnight at $80{ }^{\circ} \mathrm{C}$, were carried out with the use of (i) a Bruker-AXS S2 Range type X-ray fluorescence energy dispersive spectrometer (XRF-EDS) (Bruker, Karlsruhe, Germany) and (ii) an X-ray diffractometer (XRD)(Bruker AXS (D8 Advance type), Karlsruhe, Germany) (Cu tube, scanning range from $4^{\circ}$ to $70^{\circ}$ $2 \theta$, step $0.02^{\circ}$ and measuring time $0.2 \mathrm{~s} / \mathrm{step}$ ) with the use of the DIFFRACplus EVA v. 2006 software 
(Bruker, Karlsruhe, Germany) and the Powder Diffraction File (PDF-2) database(Bruker, Karlsruhe, Germany). A quantity of $2 \mathrm{~g}$ of each ore sample and leaching residue was also digested with the use of aqua regia and analyzed with AAS to carry out mass balance calculations [27]. Since the differences between aqua regia digestion and XRF were only minor $( \pm 5 \%)$, results presented in this paper are those derived by XRF. The functional groups present in laterite and leaching residues were identified through Fourier transform infrared (FTIR) spectroscopy using KBr pellets and a Perkin Elmer Spectrum 1000 spectrometer (Akron, OH, USA); each sample was mixed with $\mathrm{KBr}$ at a ratio 1:100 $\mathrm{w} / \mathrm{w}$ and pressed to obtain a disc. In addition, differential scanning calorimetry and thermogravimetry (DSC/TG) were performed using a Setaram LabSys Evo TG-DTA-DSC analyzer (SETARAM Inc., Cranbury, NJ, USA). The samples were heated in a nitrogen atmosphere from 40 to $1000{ }^{\circ} \mathrm{C}$ with a heating rate of $10^{\circ} \mathrm{C} / \mathrm{min}$. All analyses were carried out in duplicate and average values are given in this study.

Four leaching tests were carried out in columns to study the effect of $\mathrm{H}_{2} \mathrm{SO}_{4}$ concentration and the addition of sodium sulfite $\left(\mathrm{Na}_{2} \mathrm{SO}_{3}\right)$ in the leaching solution on $\mathrm{Ni}, \mathrm{Co}$, and other element extractions. The leaching solutions and the process parameters considered are presented in Table 1. Laboratory Plexiglas columns with a diameter of $5 \mathrm{~cm}$ and height of $50 \mathrm{~cm}$ were used. The bed consisted of $1000 \mathrm{~g}$ laterite (bed height $40 \mathrm{~cm}$ ) and two layers of $2 \mathrm{~cm}$ of silica sand placed at both ends of each column to act as filters. Cotton glass was also added at the bottom of each column to prevent transport of ultra-fine particles and precipitates and subsequent blockage of the columns. The leaching solution used, with an initial volume of $10 \mathrm{~L}$, was either $0.5 \mathrm{M}$ or $1.5 \mathrm{M} \mathrm{H}_{2} \mathrm{SO}_{4}$. The effect of the addition of 20 or $30 \mathrm{~g} / \mathrm{L} \mathrm{Na}_{2} \mathrm{SO}_{3}$ in the solution containing $1.5 \mathrm{M} \mathrm{H}_{2} \mathrm{SO}_{4}$ was also investigated. It is noted that the conditions used in the present study were the ones which were considered optimum after a series of previous tests investigating leaching of saprolitic and limonitic ores were carried out.

The leaching solution was pumped from plastic vessels with a flowrate of $3 \mathrm{~L} /$ day and collected in similar vessels. The solution was pumped upwards using a variable-speed peristaltic pump (Masterflex L/S economy variable-speed drive, Cole-Parmer Instrument Co, Vernon Hills, IL, USA) at a Darcy velocity of $152.9 \mathrm{~cm} /$ day. This means that an input flowrate of $2.08 \pm 0.1 \mathrm{~mL} / \mathrm{min}$ was used. This flowrate can be also expressed as $\sim 175.4 \mathrm{~L} /\left(\mathrm{m}^{2} \cdot \mathrm{h}\right)$. It is mentioned that in column leaching studies, velocities greater than $20 \mathrm{~cm} /$ day minimize the impact of axial (e.g. longitudinal) diffusion on transport [34]. Hence, the total empty bed contact time (EBCT), defined as the ratio of actual bed length to approach velocity, was $15.7 \mathrm{~h}$ [35].

The leaching solution was recycled every 3 days. Recirculation started after the entire feed solution passed through the column (laterite bed). The total duration of the tests was 33 days. At the end of the tests, columns were flushed with distilled water so that the final PLS volume was $\sim 10 \mathrm{~L}$. Samples from the outflow were taken initially every day and at later stages at the end of each cycle to determine the concentration of $\mathrm{Ni}, \mathrm{Co}, \mathrm{Fe}, \mathrm{Ca}, \mathrm{Al}, \mathrm{Mg}$, and Mn by Atomic Absorption Spectroscopy (AAS). pH and Eh measurements were carried out with the use of a WTW pH 7110 inoLab pH/Eh meter. Acid consumption was determined by calculating the acid strength of the initial and the solution at the end of each cycle by a titrimetric method, as proposed by Quaicoe et al. [19]. The residues were dried at $80^{\circ} \mathrm{C}$ for 1 day before characterization with the use of analytical techniques.

All leaching tests were done twice and metal concentration values in PLS given in this paper are averages; it is noted that the difference in concentration for all metals was less than $1 \%$ in all cases.

Table 1. Experimental details.

\begin{tabular}{cccc}
\hline Test Number & Strength of $\mathbf{H}_{\mathbf{2}} \mathbf{S O}_{\mathbf{4}}$ Solution $\mathbf{( M )}$ & $\mathbf{N a}_{\mathbf{2}} \mathbf{S O}_{\mathbf{3}}$ conc. (g/L) & Weight Loss (\%) \\
\hline 1 & 0.5 & & 10.5 \\
2 & 1.5 & 20 & 8.8 \\
3 & 1.5 & 30 & 8.6 \\
4 & 1.5 & 8.5 \\
\hline
\end{tabular}




\section{Results and Discussion}

\subsection{Ore Characterization}

The product of the crusher was dry sieved using a series of screens with an aperture ratio of 2 and the determined particle size distribution is presented in Figure 1. The results showed that the $80 \%$ passing size $\left(\mathrm{d}_{80}\right)$ of the raw material was $8.8 \mathrm{~mm}$. The chemical composition of each size fraction is shown in Table 2. It is seen that grinding is not selective and does not result in noticeable nickel upgrade in the finer fractions. The XRD pattern of LAI and selected leaching residues is shown in Figure 2. Chemical and mineralogical analyses showed that the ore is of limonitic type (Fe content $>32 \%$ and $\mathrm{MgO}<10 \%$ ). The main mineral phases identified in the ore are hematite $\left(\mathrm{Fe}_{2} \mathrm{O}_{3}\right)$, goethite $(\mathrm{FeO}(\mathrm{OH}))$, and quartz $\left(\mathrm{SiO}_{2}\right)$, while calcite $\left(\mathrm{CaCO}_{3}\right)$ and cryptomelane $\left(\mathrm{KMn}_{8} \mathrm{O}_{16}\right)$ are minor phases. The main Ni-bearing phases of the ore are chromite $\left(\mathrm{Cr}_{2} \mathrm{O}_{3} \cdot \mathrm{NiO}\right)$, clinochlore $\left.(\mathrm{Mg}, \mathrm{Fe})_{5} \mathrm{Al}\left(\mathrm{Si}_{3} \mathrm{Al}\right) \mathrm{O}_{10}(\mathrm{OH})_{8}\right)$, and willemseite $\left((\mathrm{Ni}, \mathrm{Mg})_{3} \mathrm{Si}_{4} \mathrm{O}_{10}(\mathrm{OH})_{2}\right)$. The mineralogy of the laterites used in the present study is quite similar to the mineralogy of other limonitic laterites originating either from the same area or from other countries and investigated in earlier studies [36,37].

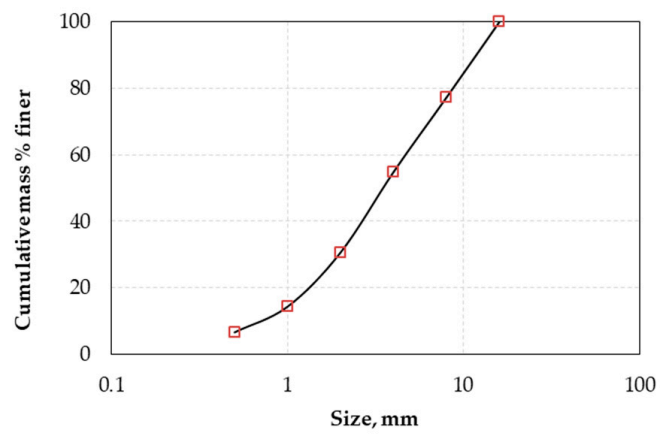

Figure 1. Particle size distribution of laterite from Agios Ioannis (LAI) used in column leaching tests.

Table 2. Chemical composition $(\% \mathrm{w} / \mathrm{w})$ of LAI size fractions.

\begin{tabular}{|c|c|c|c|c|c|c|c|c|c|c|c|c|c|}
\hline Size Fraction (mm) & $\mathrm{Ni}$ & Co & $\mathrm{Fe}_{2} \mathrm{O}_{3}$ & $\mathrm{SiO}_{2}$ & $\mathrm{Al}_{2} \mathrm{O}_{3}$ & $\mathrm{CaO}$ & $\mathrm{MgO}$ & $\mathrm{Cr}_{2} \mathrm{O}_{3}$ & $\mathrm{~K}_{2} \mathrm{O}$ & $\mathrm{TiO}_{2}$ & $\mathrm{MnO}$ & LOI & Sum \\
\hline+8 & 0.66 & 0.031 & 49.25 & 27.66 & 4.79 & 0.63 & 2.98 & 3.65 & 0.47 & 0.60 & 0.44 & 7.51 & 98.67 \\
\hline+4 & 0.49 & 0.035 & 51.75 & 27.05 & 4.94 & 0.53 & 3.11 & 2.59 & 0.51 & 0.54 & 0.32 & 7.85 & 99.72 \\
\hline+2 & 0.56 & 0.033 & 51.40 & 27.56 & 4.75 & 0.55 & 2.91 & 2.68 & 0.56 & 0.58 & 0.32 & 7.37 & 99.27 \\
\hline+1 & 0.61 & 0.031 & 49.27 & 28.12 & 5.00 & 0.76 & 3.05 & 2.52 & 0.69 & 0.58 & 0.32 & 8.00 & 98.95 \\
\hline+0.5 & 0.55 & 0.032 & 49.44 & 28.73 & 5.01 & 0.75 & 2.95 & 2.29 & 0.59 & 0.57 & 0.31 & 8.36 & 99.58 \\
\hline-0.5 & 0.67 & 0.028 & 41.20 & 32.46 & 5.87 & 1.73 & 4.02 & 2.66 & 0.74 & 0.53 & 0.37 & 9.14 & 99.42 \\
\hline Total & 0.58 & 0.032 & 49.81 & 27.98 & 4.94 & 0.69 & 3.07 & 2.82 & 0.57 & 0.57 & 0.35 & 7.81 & 99.22 \\
\hline
\end{tabular}

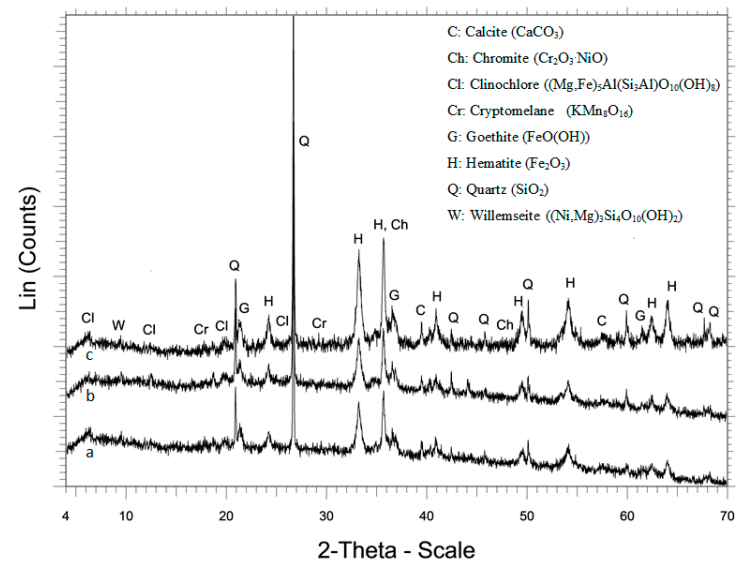

Figure 2. XRD patterns of (a) LAI, (b) residue after leaching with $1.5 \mathrm{M} \mathrm{H}_{2} \mathrm{SO}_{4}$, and (c) residue after leaching with $1.5 \mathrm{M} \mathrm{H}_{2} \mathrm{SO}_{4}$ and $20 \mathrm{~g} / \mathrm{L} \mathrm{Na}_{2} \mathrm{SO}_{3}$. 
The XRD patterns of the leaching residues, resulting from $\mathrm{H}_{2} \mathrm{SO}_{4}$ leaching with and without the use of $\mathrm{Na}_{2} \mathrm{SO}_{3}$, are shown in Figure $2 b$,c. The main difference in these patterns is the higher intensity of hematite peaks, especially when $\mathrm{Na}_{2} \mathrm{SO}_{3}$ was added in the leaching solution. No gypsum was detected in the residues, as in the case of reactor leaching of the same ore [38], due to the conditions prevailing in columns, i.e., low temperature and high $\mathrm{H}_{2} \mathrm{SO}_{4}$ concentration [39]; some gypsum may be formed but not enough to be detected by XRD.

The FTIR spectra of LAI and its residues after column leaching with $1.5 \mathrm{M} \mathrm{H}_{2} \mathrm{SO}_{4}$ and $1.5 \mathrm{M}$ $\mathrm{H}_{2} \mathrm{SO}_{4}$ with the addition of $20 \mathrm{~g} / \mathrm{L} \mathrm{Na}_{2} \mathrm{SO}_{3}$ are shown in Figure 3. In all spectra, three regions can be identified, including several low-, mid-, and higher-frequency weaker bands. The band seen at $466 \mathrm{~cm}^{-1}$ in LAI (Figure 3a), which was slightly shifted to $458 \mathrm{~cm}^{-1}$ in leaching residues (Figure 3b,c), can be attributed to the bending motions of the Al- and Si-containing phases and the formation of $\mathrm{Fe}$ phases. The peak at $784 \mathrm{~cm}^{-1}$ in LAI is mainly due to $\mathrm{Si}-\mathrm{O}-\mathrm{Si}$ symmetric stretching of bridging oxygen between $\mathrm{SiO}_{4}$ tetrahedra. The band seen at $1010 \mathrm{~cm}^{-1}$ in LAI, which has been shifted to higher values $\left(1086 \mathrm{~cm}^{-1}\right)$ in the leaching residues (Figure $\left.3 \mathrm{~b}, \mathrm{c}\right)$, is attributed to asymmetric stretching vibrations of the silicate tetrahedral network [40]. The weak band shown at $1626 \mathrm{~cm}^{-1}$ in LAI, which becomes more intense in the leaching residues and especially in the one obtained after leaching with the addition of $\mathrm{Na}_{2} \mathrm{SO}_{3}$, is probably due to $-\mathrm{OH}$ bending vibrations. The small band seen around $2360 \mathrm{~cm}^{-1}$ in LAI is mainly associated with the infrared band position of $\mathrm{HCO}_{3}{ }^{-}$ions. The band shown between 2892 and $2922 \mathrm{~cm}^{-1}$ is due to hydrocarbon stretches. The broad band seen at $3416 \mathrm{~cm}^{-1}$ only in leaching residues (Figure $3 b, c$ ) corresponds to $-\mathrm{OH}$ stretching vibrations [41]. The band seen at $3416 \mathrm{~cm}^{-1}$ only in leaching residues may be assigned to $\mathrm{Fe}^{3+}-\mathrm{OH}-\mathrm{Fe}^{3+}$ stretching and deformation vibrations [42,43].

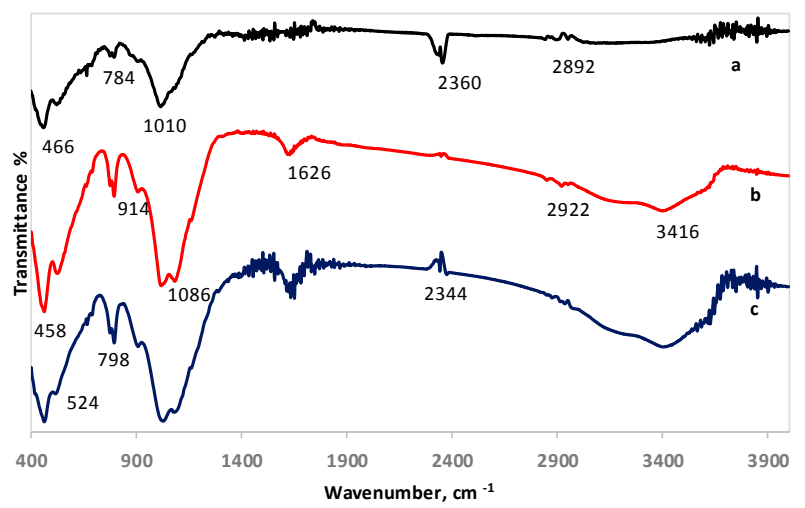

Figure 3. FTIR spectra of (a) LAI, (b) residue after column leaching with $1.5 \mathrm{M} \mathrm{H}_{2} \mathrm{SO}_{4}$, and (c) residue after column leaching with $1.5 \mathrm{M} \mathrm{H}_{2} \mathrm{SO}_{4}$ with $20 \mathrm{~g} / \mathrm{L} \mathrm{Na}_{2} \mathrm{SO}_{3}$.

The behavior of LAI and its residues during heating was investigated through DSC/TG analysis (Figure 4). The peaks at $110{ }^{\circ} \mathrm{C}$ and $140{ }^{\circ} \mathrm{C}$ in all samples (Figure 4a-c) are due to loss of free water. The peaks seen between 330 and $350^{\circ} \mathrm{C}$, also in all samples, are associated with the removal of crystalline water and $\mathrm{OH}^{-}$group from the structure of goethite as well as the formation of hematite [44]. This peak was shifted to a higher temperature $\left(350^{\circ} \mathrm{C}\right)$ in the residue obtained after leaching with the use of $\mathrm{Na}_{2} \mathrm{SO}_{3}$, probably due to the higher degree of crystallinity of goethite [45]. The peaks at 530 and $570{ }^{\circ} \mathrm{C}$ (Figure $4 \mathrm{a}, \mathrm{b}$ ) are due to phase transformations of iron, silica, and calcium compounds; these peaks are almost invisible in the leaching residue obtained after leaching with the addition of $\mathrm{Na}_{2} \mathrm{SO}_{3}$. The exothermic peak at $800{ }^{\circ} \mathrm{C}$ (Figure 4c) is associated with recrystallization of forsterite $\left(\mathrm{Mg}_{2} \mathrm{SiO}_{4}\right)$ and transformation of $\mathrm{NiSO}_{4}$ and $\mathrm{CoSO}_{4}$ to $\mathrm{NiO}$ and $\mathrm{CoO}$, respectively $[45,46]$. Concerning TG analysis, the total weight loss of LAI was almost $15 \%$ (Figure $4 \mathrm{a}$ ) and increased to $40 \%$ and $63 \%$ for the residues obtained after leaching with $1.5 \mathrm{M} \mathrm{H}_{2} \mathrm{SO}_{4}$ in the absence/presence of $20 \mathrm{~g} / \mathrm{L} \mathrm{Na}_{2} \mathrm{SO}_{3}$ (Figure $4 b, c$, respectively). 


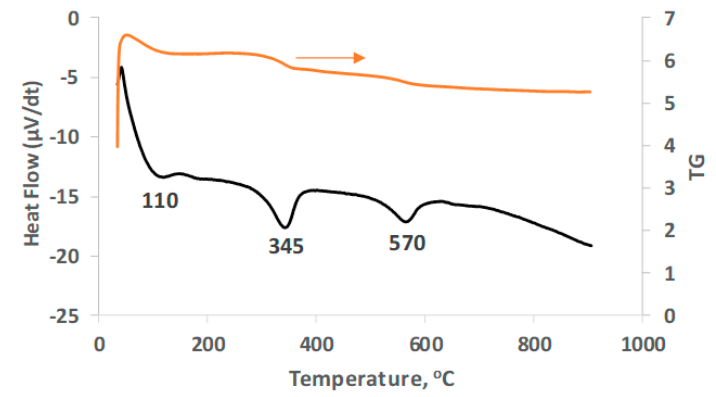

(a)

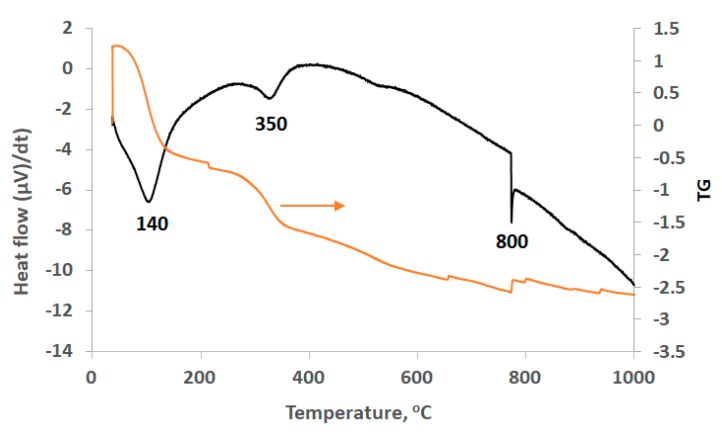

(c)

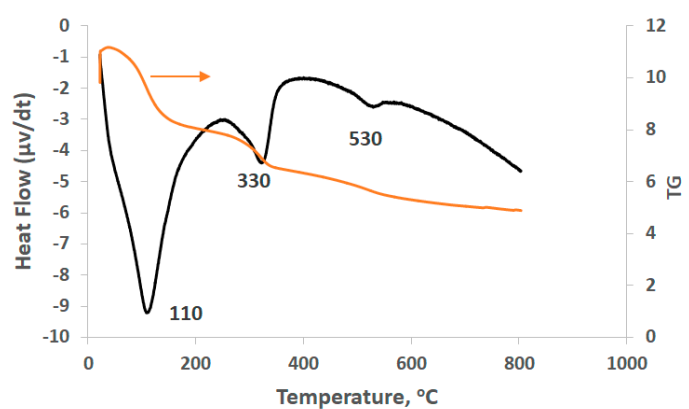

(b)

Figure 4. DSC/TG curves of (a) LAI, (b) residue after leaching with $1.5 \mathrm{M} \mathrm{H}_{2} \mathrm{SO}_{4}$, and (c) residue after leaching with $1.5 \mathrm{M} \mathrm{H}_{2} \mathrm{SO}_{4}$ with $20 \mathrm{~g} / \mathrm{L} \mathrm{Na}_{2} \mathrm{SO}_{3}$.

\subsection{Leaching Efficiency}

Figures 5-11 show the evolution of metal extractions ( $\mathrm{Ni}, \mathrm{Co}, \mathrm{Fe}, \mathrm{Mg}, \mathrm{Al}, \mathrm{Ca}$, and $\mathrm{Mn}$ ) versus time (in days) during leaching for the different column tests. It is seen that the extraction percentage for each metal increases with time but the leaching rate differs and depends on the conditions prevailing in each column.

The extraction of $\mathrm{Ni}$ and $\mathrm{Co}$ when $0.5 \mathrm{M} \mathrm{H}_{2} \mathrm{SO}_{4}$ is used is rather low and does not exceed 40 and $55 \%$, respectively; this is also due to the fact that some acid is consumed for the solubilization of $\mathrm{Mg}$ and $\mathrm{Ca}$ compounds present in the ore. Increase of the acid strength to $1.5 \mathrm{M}$ improves $\mathrm{Ni}$ and Co extractions to $60.2 \%$ and $59.0 \%$ for $\mathrm{Ni}$ and $\mathrm{Co}$, respectively. Further increase of the $\mathrm{Ni}$ and $\mathrm{Co}$ extractions is shown when $20 \mathrm{~g} / \mathrm{L}$ of $\mathrm{Na}_{2} \mathrm{SO}_{3}$ is added to the leaching solution, reaching $73.5 \%$ and $84.1 \%$, respectively. Increase of the addition of $\mathrm{Na}_{2} \mathrm{SO}_{3}$ to $30 \mathrm{~g} / \mathrm{L}$ only marginally affects extraction of $\mathrm{Ni}$ and $\mathrm{Co}$ : Ni extraction increases from 73.5 to $76.0 \%$, whereas Co extraction decreases from 84.1 to $75.5 \%$; this decrease may be due to the formation of neophases and their precipitation in the residues.

The extraction of $\mathrm{Ni}$ and $\mathrm{Co}$ is increased in the presence of $\mathrm{Na}_{2} \mathrm{SO}_{3}$ as a result of the following reactions. In the presence of $\mathrm{H}_{2} \mathrm{SO}_{4}, \mathrm{Na}_{2} \mathrm{SO}_{3}$ reacts with $\mathrm{H}^{+}$ions to form $\mathrm{H}_{2} \mathrm{SO}_{3}$, as shown in Reaction (1). Then, $\mathrm{H}_{2} \mathrm{SO}_{3}$ is dissociated according to Reaction (2).

$$
\begin{gathered}
\mathrm{Na}_{2} \mathrm{SO}_{3}+\mathrm{H}_{2} \mathrm{SO}_{4}=\mathrm{Na}_{2} \mathrm{SO}_{4}+\mathrm{H}_{2} \mathrm{SO}_{3} \\
\mathrm{H}_{2} \mathrm{SO}_{3}=\mathrm{H}^{+}+\mathrm{HSO}_{3}^{-}=\mathrm{H}_{2} \mathrm{O}+\mathrm{SO}_{2}(\mathrm{aq})
\end{gathered}
$$

Goethite reacts according to the following reactions ((3) and (4)) and, thus, nickel associated to this mineral phase is extracted.

$$
\begin{aligned}
& 2 \mathrm{FeOOH}(\mathrm{s})+2 \mathrm{H}^{+}+\mathrm{SO}_{2}(\mathrm{aq})=2 \mathrm{Fe}^{2+}+\mathrm{SO}_{4}^{2-}+2 \mathrm{H}_{2} \mathrm{O} \\
& 2 \mathrm{FeOOH}(\mathrm{s})+4 \mathrm{H}^{+}+\mathrm{SO}_{3}^{2-}(\mathrm{aq})=2 \mathrm{Fe}^{2+}+\mathrm{SO}_{4}^{2-}+3 \mathrm{H}_{2} \mathrm{O}
\end{aligned}
$$


The $\mathrm{SO}_{2}$ (aq) generated from Reaction (2) will lower the potential of Reactions (3) and (4) and accelerate $\mathrm{Fe}$ extraction and $\mathrm{Ni}$ liberation from goethite. An in-depth analysis of the leaching chemistry of laterites with the use of $\mathrm{H}_{2} \mathrm{SO}_{4}$ in the presence of $\mathrm{H}_{2} \mathrm{SO}_{3}$ is given in a recent paper [24].

It is seen from Reactions (3) and (4) that less acid is required for the initial dissolution of goethite, namely 0.5 or 1 mole of $\mathrm{H}_{2} \mathrm{SO}_{4}$ per mole of goethite, compared with the consumption of acid without the presence of $\mathrm{H}_{2} \mathrm{SO}_{3}$, which is 1.5 moles per mole of goethite [47], as shown in Reaction (5).

$$
\mathrm{FeOOH}(\mathrm{s})+3 \mathrm{H}^{+}=\mathrm{Fe}^{3+}+2 \mathrm{H}_{2} \mathrm{O}
$$

Iron extraction is, in general, very low; however, the increase of the acid strength and the addition of $\mathrm{Na}_{2} \mathrm{SO}_{3}$ result in an increase of Fe extraction which does not exceed 8.2\%. It is known that $\mathrm{Fe}$ extraction during laterite leaching is the main parameter that defines the selectivity of the process. In this study, the low Fe extraction is due to the room temperature used, the use of columns instead of stirred reactors, the coarser feed size used in comparison to the size used in agitated leaching, and the precipitation of iron compounds during leaching. In the study carried out by Luo et al. [24] and involving leaching of a limonitic laterite with liquid/solid (L/S) ratio 10:1 and $12 \%(\mathrm{w} / \mathrm{w}) \mathrm{H}_{2} \mathrm{SO}_{4}$ at $90{ }^{\circ} \mathrm{C}$ with or without the use of $\mathrm{Na}_{2} \mathrm{SO}_{3}, \mathrm{Fe}$ extraction after $6 \mathrm{~h}$ was much higher and reached $70 \%$ and $55 \%$, respectively. It is known that in the conditions prevailing in our experiments, iron can be removed through the formation of hydronium jarosites and ferrihydrites. The formation of hydronium jarosites is favored at very low $\mathrm{pH}$ values, i.e., $\mathrm{pH}=0.2$, whereas hematite can only be formed when tests are carried out in much higher temperatures [44].

The maximum extractions of the other three elements that affect the selectivity of leaching, namely, $\mathrm{Mg}$, Al, and $\mathrm{Ca}$, do not exceed $40.2,23.3$, and $51.0 \%$, respectively, in the optimum conditions $(1.5 \mathrm{M}$ $\mathrm{H}_{2} \mathrm{SO}_{4}, 20 \mathrm{~g} / \mathrm{L} \mathrm{Na}_{2} \mathrm{SO}_{3}$ ). The low extraction percentages of these elements during laterite leaching with the use of $\mathrm{H}_{2} \mathrm{SO}_{4}$ is an advantage of column leaching, since the solubility of metal sulphates in water increases with the increase of temperature; on the other hand, inverse solubilities may be noticed at elevated temperatures. It is known that limonitic laterites have lower content of $\mathrm{Ca}$ and $\mathrm{Mg}$ and higher content of Al compounds compared with saprolitic ores; this affects the selectivity of the process, especially when leaching is carried out in stirred reactors and higher temperature [38].

$\mathrm{pH}$ values were very low, close to zero, in all column leaching tests; the only exception was noted in the use of $0.5 \mathrm{M} \mathrm{H}_{2} \mathrm{SO}_{4}$, where $\mathrm{pH}$ increased with time to 0.36 at the end of the test. On the other hand, final Eh values decreased slightly with the addition of $\mathrm{Na}_{2} \mathrm{SO}_{3}$ and varied between 410 and $370 \mathrm{mV}$ when $0.5 \mathrm{M} \mathrm{H}_{2} \mathrm{SO}_{4}$ and $1.5 \mathrm{M} \mathrm{H}_{2} \mathrm{SO}_{4}$ with $30 \mathrm{~g} / \mathrm{L} \mathrm{Na}_{2} \mathrm{SO}_{3}$ were used, respectively.

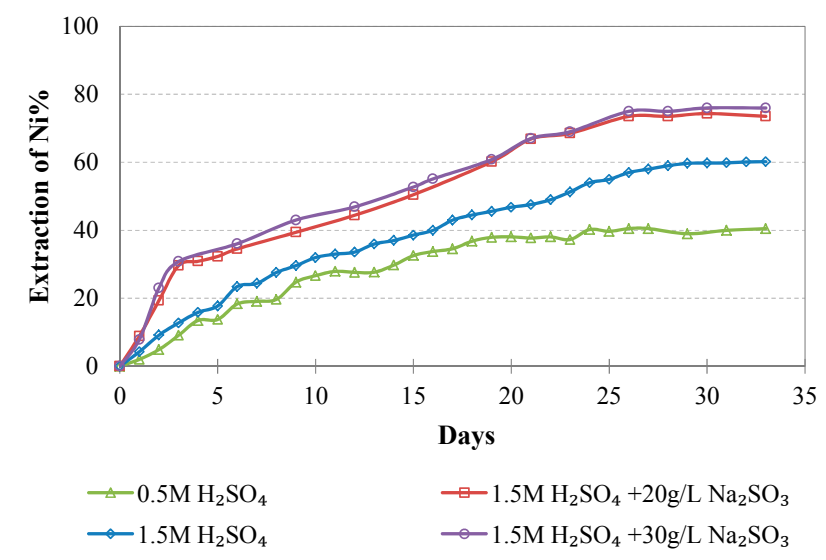

Figure 5. Evolution of \% Ni extraction vs time during LAI leaching for different tests. 


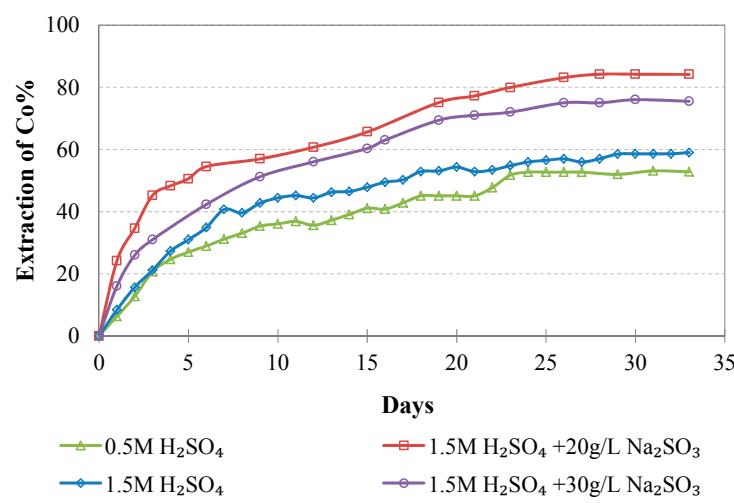

Figure 6. Evolution of \% Co extraction vs time during LAI leaching for different tests.
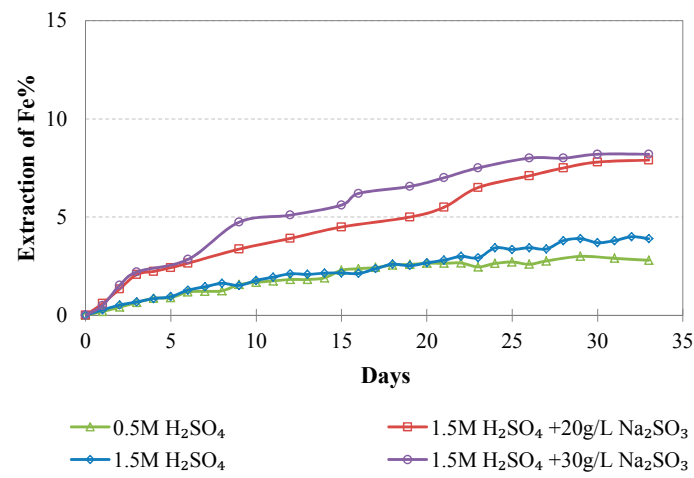

Figure 7. Evolution of \% Fe extraction vs time during LAI leaching for different tests.

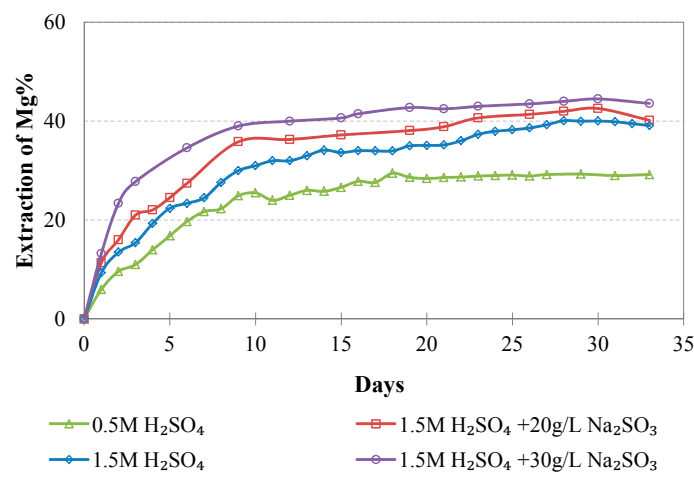

Figure 8. Evolution of \% Mg extraction vs time during LAI leaching for different tests.

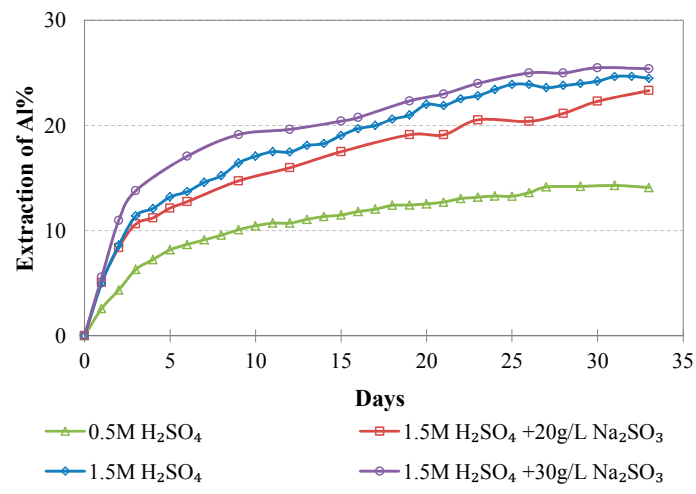

Figure 9. Evolution of \% Al extraction vs time during LAI leaching for different tests. 


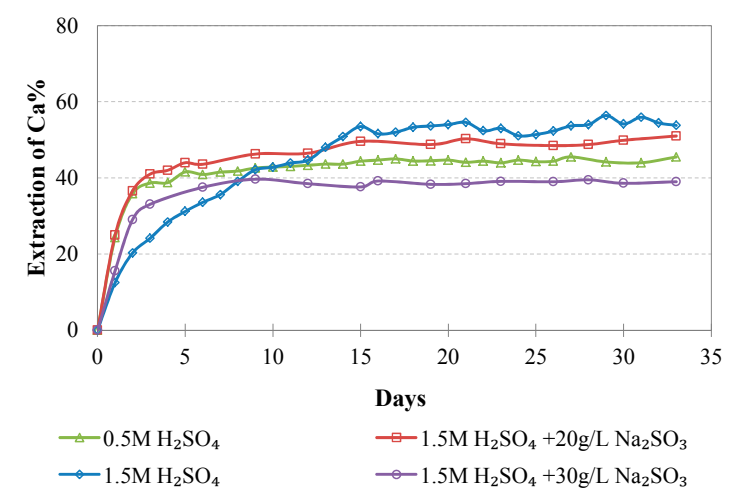

Figure 10. Evolution of \% Ca extraction vs time during LAI leaching for different tests.

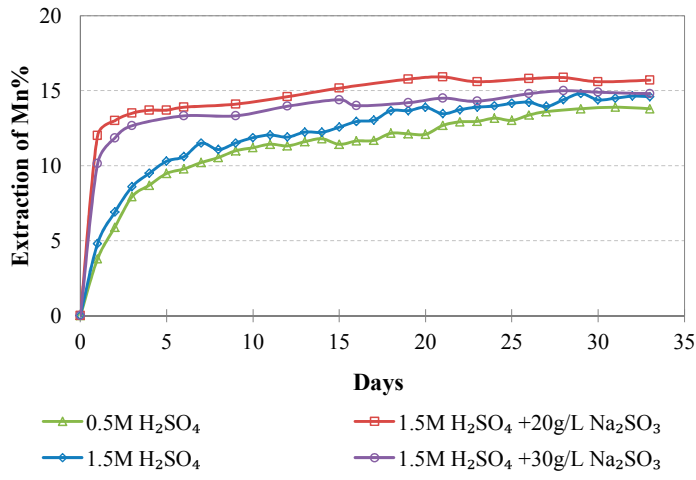

Figure 11. Evolution of \% Mn extraction vs time during LAI leaching for different tests.

Table 3 presents the concentration of $\mathrm{Ni}$ and other main elements in the PLS in order to assess the selectivity of leaching in each case by comparing the concentration ratios of $\mathrm{Ni} / \mathrm{Fe}, \mathrm{Ni} / \mathrm{Mg}, \mathrm{Ni} / \mathrm{Ca}$, and $\mathrm{Ni} / \mathrm{Al}$. The comparisons done do not include the use of $0.5 \mathrm{M} \mathrm{H}_{2} \mathrm{SO}_{4}$, which does not result in high $\mathrm{Ni}$ and Co extractions, or the use of $30 \mathrm{~g} / \mathrm{L} \mathrm{Na}_{2} \mathrm{SO}_{3}$, which does not seem to improve the efficiency of leaching compared with the addition of $20 \mathrm{~g} / \mathrm{L}$.

It is seen from the results that the addition of $20 \mathrm{~g} / \mathrm{L} \mathrm{Na}_{2} \mathrm{SO}_{3}$ in the leaching medium improves the selectivity of leaching compared with the test which involves only the addition of $1.5 \mathrm{M} \mathrm{H}_{2} \mathrm{SO}_{4}$, as the ratios $\mathrm{Ni} / \mathrm{Mg}, \mathrm{Ni} / \mathrm{Ca}$, and $\mathrm{Ni} / \mathrm{Al}$ increase by almost 18,30 , and $28 \%$, respectively. The only exception is the ratio $\mathrm{Ni} / \mathrm{Fe}$ which decreases by almost $40 \%$; this is mainly due to the much higher concentration of Fe in the PLS, which increases from 1.56 to $2.88 \mathrm{~g} / \mathrm{L}$, compared with the concentration of $\mathrm{Ni}$, which also increases from 0.40 to $0.45 \mathrm{~g} / \mathrm{L}$. It is worth mentioning that the purification of PLS for the recovery of $\mathrm{Ni}$ and $\mathrm{Co}$ as well as of other useful elements including $\mathrm{Mg}$, has been extensively investigated [48-50].

Table 3. Comparison of pregnant leach solution (PLS) quality and selectivity of each leaching medium.

\begin{tabular}{|c|c|c|c|c|c|c|c|c|c|c|}
\hline \multirow{2}{*}{ Test No. } & $\mathrm{Ni}$ & Co & $\mathrm{Fe}$ & Mg & $\mathrm{Ca}$ & Al & \multirow{2}{*}{$\mathrm{Ni} / \mathrm{Fe}$} & \multirow{2}{*}{$\mathrm{Ni} / \mathrm{Mg}$} & \multirow{2}{*}{$\mathrm{Ni} / \mathrm{Ca}$} & \multirow{2}{*}{$\mathrm{Ni} / \mathrm{Al}$} \\
\hline & \multicolumn{6}{|c|}{$(\mathrm{mg} / \mathrm{L})$} & & & & \\
\hline 1 & 266 & 19.0 & 1105 & 611 & 263 & 422 & 0.24 & 0.43 & 1.01 & 0.63 \\
\hline 2 & 399 & 21.5 & 1556 & 829 & 314 & 741 & 0.26 & 0.48 & 1.27 & 0.54 \\
\hline 3 & 445 & 28.0 & 2878 & 776 & 271 & 645 & 0.15 & 0.57 & 1.64 & 0.69 \\
\hline 4 & 450 & 24.7 & 2922 & 823 & 203 & 687 & 0.15 & 0.55 & 2.22 & 0.66 \\
\hline
\end{tabular}

Table 4 compares the results of this study with those of other leaching studies pertinent to the leaching of limonitic laterites carried out over the last 25 years, as derived from an extensive literature search. Some data presented in this table were derived after calculations done by the authors of this study. 
Table 4. Comparison of results of various column leaching studies.

\begin{tabular}{|c|c|c|c|c|c|c|c|c|c|c|c|c|}
\hline \multirow{2}{*}{ Ore Type } & \multirow{2}{*}{$\begin{array}{c}\mathrm{Ni} \\
\%\end{array}$} & \multirow{2}{*}{$\begin{array}{l}\text { Weight } \\
\text { (kg ore) }\end{array}$} & \multirow{2}{*}{$\begin{array}{l}\text { Ore Size } \\
(\mathrm{mm})\end{array}$} & \multirow{2}{*}{$\begin{array}{l}\mathrm{H}_{2} \mathrm{SO}_{4} \\
\text { (N) }\end{array}$} & \multirow{2}{*}{$\begin{array}{l}\text { Duration } \\
\text { (days) }\end{array}$} & \multirow{2}{*}{$\begin{array}{l}\text { Flow Rate } \\
\text { (L/day) }\end{array}$} & \multicolumn{3}{|c|}{ Extraction (\%) } & \multirow{2}{*}{$\begin{array}{l}\text { Ni/Fe in } \\
\quad \text { PLS }\end{array}$} & \multirow{2}{*}{$\begin{array}{l}\text { Acid Consumption } \\
\text { (kg/tonne ore) }\end{array}$} & \multirow{2}{*}{ Ref. } \\
\hline & & & & & & & $\mathrm{Ni}$ & $\mathrm{Fe}$ & Co & & & \\
\hline $\mathrm{L}$ & 0.73 & $8-22$ & $<6.75$ & 1 & 90 & 4.5 & 80 & 14.0 & 65 & 0.5 & 380 & [31] \\
\hline $\mathrm{L}$ & 1.05 & 6.6 & $<15$ & 3 & 10 & 4.0 & 60 & 8.1 & 45 & 0.2 & 284 & [32] \\
\hline \multirow{3}{*}{ SG } & 1.01 & & $<15$ (a) & 4 & 102 & 2.3 & 71 & & 45 & & 684 & \multirow{4}{*}[4,11,51]{} \\
\hline & 1.01 & 5 & $<2(\mathrm{a})$ & 4 & 104 & 2.3 & 81 & & 67 & & 569 & \\
\hline & 1.25 & & $<0.038$ (a) & 4 & 101 & 2.3 & 89 & & 80 & & 541 & \\
\hline G & 0.96 & 5 & $<15$ (a) & 4 & 106 & 2.3 & 55 & & & & 453 & \\
\hline G & 0.96 & 5 & $<2(\mathrm{a})$ & 4 & 100 & 2.3 & 62.7 & 48.5 & 55.6 & 0.03 & 525 & [19] \\
\hline $\mathrm{L}$ & 0.58 & 1 & $<16$ & 3 & 33 & 3.0 & 60.2 & 3.9 & 59.0 & 0.26 & 764.4 & \multirow{2}{*}{ This study } \\
\hline $\mathrm{L}$ & 0.58 & 1 & $<16$ & $3+(s s)$ & 33 & 3.0 & 73.5 & 7.9 & 84.1 & 0.15 & 688.8 & \\
\hline
\end{tabular}

L: Limonitic laterite, SG: Siliceous goethitic laterite, G: Goethitic laterite, (ss): Sodium sulfite, (a): use of agglomerated ore. 
Agatzini-Leonardou and Dimaki [31] performed large column leaching tests on low-grade limonitic laterites using $0.5 \mathrm{M} \mathrm{H}_{2} \mathrm{SO}_{4}$. Extractions of $80 \%$ for $\mathrm{Ni}$ and $60 \%$ for Co were achieved after 90 days of leaching, while acid consumption was around $380 \mathrm{~kg} \mathrm{H}_{2} \mathrm{SO}_{4}$ /tonne ore. In another leaching study involving different types of laterites, Agatzini-Leonardou and Zafiratos [32] noted that the high calcite content in the ore reduces the permeability of the heap and adversely affects leaching. The recoveries achieved for the limonitic type after 10 days of leaching reached $60 \%$ for $\mathrm{Ni}$ and $45 \%$ for Co. The Fe/Ni ratio was reduced from 37:1 in the limonitic ore to 5:1 in the PLS. The acid consumption was around $284 \mathrm{~kg} \mathrm{H}_{2} \mathrm{SO}_{4}$ / tonne ore. Other studies investigated the leaching behavior of goethitic (G) and siliceous goethitic laterites (SG) $[4,11,51]$ and found that the particle size of the agglomerated ore $(<15,<2$, and $<0.038 \mathrm{~mm}$ ) had a significant impact on $\mathrm{Ni}$ and Co extractions which increased with decreasing feed size, also resulting in reduction of acid consumption. Quite similar results were obtained in the study by Quaicoe et al. [19] who performed column leaching tests using $<2 \mathrm{~mm}$ agglomerated goethitic ore. Extractions of $62.7 \%$ for $\mathrm{Ni}$ and $55.6 \%$ for Co were achieved after 100 days of leaching. The most interesting results of the present study, which involved leaching of a very poor laterite $(0.58 \% \mathrm{Ni})$, are the good extractions of $\mathrm{Ni}$ and $\mathrm{Co}$, which exceed 70 and $80 \%$, respectively, when $\mathrm{Na}_{2} \mathrm{SO}_{3}$ is added in the leaching solution; the very low extraction of $\mathrm{Fe}$, which remains below $8 \%$; and the short duration (33 days). It is worth mentioning that the higher acid consumption noted in the present study may be decreased if bigger quantities of ore are leached in larger columns with the use of the same volume of leaching solution; this is an issue that is currently under study.

Leaching results of the present and earlier studies indicated that the variability in the efficiency of column leaching of limonitic laterites depends on the complexity of the ore and the strong bonding of $\mathrm{Ni}$ with iron minerals, compared with clay-like and high-magnesium ores (i.e., saprolitic) [52,53]. As mentioned in an excellent recent study [54], a full and comprehensive mineralogical characterization of the ore is necessary, especially at the mineral grain scale, in order to fully understand the overall leach behavior. The same authors also proved that the experimental scale noticeably affects the leaching behavior of ores at ambient conditions and proposed that the use of synchrotron methods is required to ascertain the coordination chemistry of key elements within both the fresh ore and leaching residues, in order to elucidate mineral formation and identify the major leaching mechanisms.

Other crucial factors that affect the economics of the process are the efficient control of Fe and other secondary elements' co-extraction and the possibility to recover saleable byproducts, such as $\mathrm{MgO}$ and $\mathrm{MnO}_{2}$, during PLS purification. Finally, in order to minimize the environmental impacts and improve the environmental footprint of the process, the leaching residues may be alkali activated for the production of inorganic polymers. By taking into account that the residues contain sufficient amounts of $\mathrm{SiO}_{2}$ and $\mathrm{Al}_{2} \mathrm{O}_{3}$, the residues may be transformed into solid matrices comprising a $\mathrm{Si}-\mathrm{O}-\mathrm{Al}$ network and exhibiting beneficial physical and chemical properties, including high early strength, low shrinkage and porosity, as well as high fire and corrosion resistance. These new materials may find several applications, mainly in the construction sector $[55,56]$.

\section{Conclusions}

The results of the present study are considered very promising and confirm the potential of column leaching of very low-grade Greek limonitic laterites with the use of $1.5 \mathrm{M} \mathrm{H}_{2} \mathrm{SO}_{4}$ and the addition of $20 \mathrm{~g} / \mathrm{L} \mathrm{Na}_{2} \mathrm{SO}_{3}$. These types of laterites cannot be treated economically with the use of pyrometallurgical techniques due to the extremely high energy requirements. The experimental results indicated high extractions of $\mathrm{Ni}$ and $\mathrm{Co}$, namely, 73.5 and $84.1 \%$, respectively, while the extractions of $\mathrm{Fe}, \mathrm{Mg}$, $\mathrm{Al}$, and $\mathrm{Ca}$ were quite low, namely, $7.9,40.2,23.3$, and 51.0\%, respectively. The low extractions of the unwanted elements are the result of the ore granulometry and the low temperature used.

Further studies are required though to optimize leaching efficiency with the use of larger columns and ore quantities in order to enrich the quality of the PLS, improve selectivity, and reduce acid consumption. The use of agglomerates and the presence of catalysts to accelerate the leaching rate are also issues which are currently under study. In addition, a full and comprehensive mineralogical 
characterization of the ore and the leaching residues is necessary in order to fully elucidate the overall leach behavior and identify the major leaching mechanisms.

In order to minimize the environmental impacts and improve the environmental footprint of the process, the leaching residues can be alkali activated for the production of inorganic polymers and their potential use in the construction sector. This subject is also under study.

Author Contributions: K.K. designed the experiments, critically analyzed results, and reviewed the paper. E.P. performed a literature search, carried out experiments and analytical techniques, analyzed data, and wrote a first draft of the paper. O.P. carried out experiments and analyzed data. A.K. carried out analytical techniques and analyzed data.

Acknowledgments: The authors would like to acknowledge the financial support of European Commission in the frame of Horizon 2020 project "Metal recovery from low-grade ores and wastes", www.metgrowplus.eu, Grant Agreement $\mathrm{n}^{\circ} 690088$.

Conflicts of Interest: The authors declare no conflicts of interest.

\section{References}

1. Kursunoglu, S.; Kaya, M. Atmospheric pressure acid leaching of Caldag lateritic nickel ore. Int. J. Miner. Process. 2016, 150, 1-8. [CrossRef]

2. Zeng, X.; Zhan, C.; Lu, J.; Amine, K. Stabilization of a high capacity and high-power nickel-based cathode for Li-Ion batteries. Chem 2018, 4, 690-704. [CrossRef]

3. Mohammadreza, F.; Mohammad, N.; Ziaeddin, S.S. Nickel extraction from low grade laterite by agitation leaching at atmospheric pressure. Int. J. Min. Sci. Technol. 2014, 24, 543-548. [CrossRef]

4. Nosrati, A.; Quast, K.; Xu, D.; Skinner, W.; Robinson, D.J.; Addai-Mensah, J. Agglomeration and column leaching behaviour of nickel laterite ores: Effect of ore mineralogy and particle size distribution. Hydrometallurgy 2014, 146, 29-39. [CrossRef]

5. MacCarthy, J.; Nosrati, A.; Skinner, W.; Addai-Mensah, J. Atmospheric acid leaching mechanisms and kinetics and rheological studies of a low grade saprolitic nickel laterite ore. Hydrometallurgy 2016, 160, $26-37$. [CrossRef]

6. Dalvi, A.D.; Bacon, W.G.; Osborne, R.C. The past and the future of nickel laterites. In Proceedings of the Prospectors \& Developers Association of Canada (PDAC) 2004 International Convention, Trade Show \& Investors Exchange, Toronto, ON, Canada, 7-10 March 2004.

7. Girgin, I.; Obut, A.; Ucyildiz, A. Dissolution behaviour of a Turkish lateritic nickel ore. Miner. Eng. 2011, 24, 603-609. [CrossRef]

8. Onal, M.A.R.; Topkaya, Y.A. Pressure acid leaching of Çaldağ lateritic nickel ore: An alternative to heap leaching. Hydrometallurgy 2014, 142, 98-107. [CrossRef]

9. Takeda, O.; Lu, X.; Miki, T.; Nakajima, K. Thermodynamic evaluation of elemental distribution in a ferronickel electric furnace for the prospect of recycling pathway of nickel. Resour. Conserv. Recycl. 2018, 133, 362-368. [CrossRef]

10. Wang, Z.; Chu, M.; Liu, Z.; Wang, H.; Zhao, W.; Gao, L. Preparing Ferro-Nickel Alloy from Low-Grade Laterite Nickel Ore Based on Metallized Reduction-Magnetic Separation. Metals 2017, 7, 313. [CrossRef]

11. Quast, K.; Xu, D.; Skinner, W.; Nosrati, A.; Hilder, T.; Robinson, D.J.; Addai-Mensah, J. Column leaching of nickel laterite agglomerates: Effect of feed size. Hydrometallurgy 2013, 134, 144-149. [CrossRef]

12. Oxley, A.; Smith, M.E.; Caceres, O. Why heap leach nickel laterites? Miner. Eng. 2016, 88, 53-60. [CrossRef]

13. Alibhai, K.A.K.; Dudeney, A.W.L.; Leak, D.J.; Agatzini, S.; Tzeferis, P. Bioleaching and bioprecipitation of nickel and iron from laterites. FEMS Microbiol. Rev. 1993, 11, 87-95. [CrossRef]

14. du Plessis, C.A.; Slabbert, W.; Hallberg, K.B.; Johnson, D.B. Ferredox: A biohydrometallurgical processing concept for limonitic nickel laterites. Hydrometallurgy 2011, 109, 221-229. [CrossRef]

15. Watling, H.R.; Elliot, A.D.; Fletcher, H.M.; Robinson, D.J.; Sully, D.M. Ore mineralogy of nickel laterites: Controls on processing characteristics under simulated heap-leach conditions. Aust. J. Earth Sci. 2011, 58, 725-744. [CrossRef]

16. Duyvesteyn, W.P.C.; Liu, H.; Davis, M.J. Heap Leaching of Nickel Containing Ore. U.S. Patent 6,312,500 B1, 6 November 2001. 
17. Horizonte, S.G.; Horizonte, D.O. Process for Extraction of Nickel, Cobalt, and Other Base Metals from Laterite Ores by Using Heap Leaching and Product Containing Nickel, Cobalt, and Other Metals from Laterite Ores. European Patent EP 1790739 A1, 21 June 2007.

18. Elliot, A.; Fletcher, H.; Li, J.; Watling, H.; Robinson, D.J. Heap leaching of nickel laterites-A challenge and an opportunity. In Hydrometallurgy of Nickel and Cobalt 2009, Proceeding of the 39th Annual Hydrometallurgy Meeting Held in the Conjunction with the 48th Annual Conference of Metallurgists, Sudbury, ON, Canada, 23-26 August 2009; Budac, J.J., Fraser, R., Mihaylov, I., Papangelakis, V.G., Robinson, D.J., Eds.; Canadian Institute of Mining, Metallurgy and Petroleum: Montreal, QC, Canada, 2009; pp. 537-549.

19. Quaicoe, I.; Nosrati, A.; Skinner, W.; Addai, M.J. Agglomeration and column leaching behaviour of goethitic and saprolitic nickel laterite ores. Miner. Eng. 2014, 65, 1-8. [CrossRef]

20. Das, G.K.; de Lange, J.A.B. Reductive atmospheric acid leaching of West Australian smectitic nickel laterite in the presence of sulphur dioxide and copper (II). Hydrometallurgy 2011, 105, 264-269. [CrossRef]

21. Lee, H.Y.; Kim, S.G.; Oh, J.K. Electrochemical leaching of nickel from low-grade laterites. Hydrometallurgy 2005, 77, 263-268. [CrossRef]

22. Senanayake, G.; Das, G.K. A comparative study of leaching kinetics of limonitic laterite and synthetic iron oxides in sulfuric acid containing sulfur dioxide. Hydrometallurgy 2004, 72, 59-72. [CrossRef]

23. Youzbashi, A.A.; Dixit, S.G. Leaching of nickel from supported nickel waste catalyst using aqueous sulfur dioxide solution. Metall. Trans. B 1991, 22, 775-781. [CrossRef]

24. Luo, J.; Li, G.; Rao, M.; Peng, Z.; Zhang, Y.; Jiang, T. Atmospheric leaching characteristics of nickel and iron in limonitic laterite with sulfuric acid in the presence of sodium sulfite. Miner. Eng. 2015, 78, 38-44. [CrossRef]

25. Zevgolis, E.; Zografidis, C.; Halikia, I. The reducibility of the Greek nickeliferous laterites: A review. Miner. Process. Extract. Metall. 2010, 119, 9-17. [CrossRef]

26. Bartzas, G.; Komnitsas, K. Life cycle assessment of FeNi production in Greece: A. case study. Resour. Conserv. Recycl. 2015, 105, 113-122. [CrossRef]

27. Komnitsas, K. Kinetic Study of Laterite Leaching with Sulfuric Acid at Atmospheric Pressure. Bachelor's Thesis, National Technical University of Athens, Athens, Greece, 1983. (In Greek)

28. Komnitsas, K. High Pressure acid Leaching of Laterites. Ph.D. Thesis, National Technical University of Athens, Athens, Greece, 1988. (In Greek)

29. Kontopoulos, A.; Komnitsas, K. Sulphuric acid Pressure Leaching of Low-Grade Greek Laterites. In Proceedings of the 1st International Symposium on Hydrometallurgy, Beijing, China, 12-15 October 1988; Zheng, Y.L., Xu, J.Z., Eds.; Pergamon Press: Oxford, UK, 1988; pp. 140-144.

30. Panagiotopoulos, N.; Agatzini, S.; Kontopoulos, A. Extraction of nickel and cobalt from serpentinic type laterites by atmospheric pressure sulphuric acid leaching. In Proceedings of the Technical Sessions at the 115th TMS-AIME Annual Meeting, New Orleans, LA, USA, 2-6 March 1986; p. A86-30.

31. Agatzini-Leonardou, S.; Dimaki, D. Heap leaching of poor nickel laterites by sulphuric acid at ambient temperature. In Hydrometallurgy '94; Springer: Dordrecht, The Netherlands, 1994; pp. 193-208.

32. Agatzini-Leonardou, S.; Zafiratos, I.G. Beneficiation of a Greek serpentinic nickeliferous ore part II. Sulphuric acid heap and agitation leaching. Hydrometallurgy 2004, 74, 267-275. [CrossRef]

33. Agatzini-Leonardou, S.; Zafiratos, J.G.; Spathis, D. Beneficiation of a Greek serpentinic nickeliferous orePart I: Mineral processing. Hydrometallurgy 2004, 74, 259-265. [CrossRef]

34. Komnitsas, K.; Bartzas, G.; Paspaliaris, I. Inorganic contaminant fate assessment in zero-valent iron treatment walls. Environ. Forensics 2006, 7, 207-217. [CrossRef]

35. Komnitsas, K.; Bartzas, G.; Paspaliaris, I. Modeling of reaction front progress in fly ash permeable reactive barriers. Environ. Forensics 2006, 7, 219-231. [CrossRef]

36. Alevizos, G. Mineralogy, Geochemistry and Genesis of the Sedimentary Nickeliferous Iron-Ores of Locris (Central Greece). Ph.D. Thesis, Technical University of Crete, Chania, Greece, 1997.

37. Li, G.; Rao, M.; Jiang, T.; Huang, Q.; Peng, Z. Leaching of limonitic laterite ore by acidic thiosulfate solution. Miner. Eng. 2011, 24, 859-863. [CrossRef] 
38. Mystrioti, C.; Papassiopi, N.; Xenidis, A.; Komnitsas, K. Comparative Evaluation of Sulfuric and Hydrochloric Acid Atmospheric Leaching for the Treatment of Greek Low Grade Nickel Laterites. In Extraction 2018, Proceedings of the First Global Conference on Extractive Metallurgy, The Minerals, Metals $\mathcal{E}$ Materials Series, Ottawa, QC, Canada, 26-29 August 2018; Davis, B.R., Moats, M.S., Wang, S., Gregurek, D., Kapusta, J., Battle, T.P., Schlesinger, M.E., Flores, G.R.A., Jak, E., Goodall, G., et al., Eds.; Springer: Cham, Switzerland, 2018; pp. 1753-1764.

39. Farrah, H.E.; Lawrance, G.A.; Wanless, E.J. Solubility of calcium sulfate salts in acidic manganese sulfate solutions from 30 to $105^{\circ} \mathrm{C}$. Hydrometallurgy 2007, 86, 13-21. [CrossRef]

40. Rinaudo, C.; Gastaldi, D.; Belluso, E. Characterization of chrysotile, antigorite, and lizardite by FT-Raman spectroscopy. Can. Mineral. 2003, 41, 883-890. [CrossRef]

41. Madejov, J.; Janek, M.; Komadel, P.; Herbert, H.J.; Moog, H.C. FTIR analyses of water in MX-80 bentonite compacted from high salinary salt solution systems. Appl. Clay Sci. 2002, 20, 255-271. [CrossRef]

42. Petit, S.; Decarreau, A. Hydrothermal $\left(200{ }^{\circ} \mathrm{C}\right)$ synthesis and crystal chemistry of iron rich kaolinites. Clay Miner. 1990, 25, 181-196. [CrossRef]

43. Delineau, T.; Allard, T.; Muller, J.P.; Barres, O.; Yvon, J.; Cases, J.M. FTIR reflectance vs. EPR studies of structural iron in kaolinites. Clays Clay Miner. 1994, 42, 308-320. [CrossRef]

44. Stopić, S.; Friedrich, B.; Fuchs, R. Sulphuric acid leaching of the Serbian nickel lateritic ore. Erzmetall 2003, 56, 198-203.

45. Ma, B.; Yang, W.; Pei, Y.; Wang, C.; Jin, B. Effect of activation pretreatment of limonitic laterite ores using sodium fluoride and sulfuric acid on water leaching of nickel and cobalt. Hydrometallurgy 2017, 169, 411-417. [CrossRef]

46. Luo, W.; Feng, Q.; Ou, L.; Zhang, G.; Chen, Y. Kinetics of saprolitic laterite leaching by sulphuric acid at atmospheric pressure. Miner. Eng. 2010, 23, 458-462. [CrossRef]

47. Georgiou, D.; Papangelakis, V. Sulphuric acid pressure leaching of a limonitic laterite: Chemistry and kinetics. Hydrometallurgy 1998, 49, 23-46. [CrossRef]

48. Agatzini-Leonardou, S.; Tsakiridis, P.E.; Oustadakis, P.; Karidakis, T.; Katsiapi, A. Hydrometallurgical process for the separation and recovery of nickel from sulphate heap leach 271 liquor of nickeliferous laterite ores. Miner. Eng. 2009, 22, 1181-1192. [CrossRef]

49. Mihaylov, I.; Krause, E.; Okita, Y.; Perraud, J.J. The Development of a novel hydrometallurgical process for nickel and cobalt recovery from Goro laterite ore. CIM Bull. 2000, 93, 124-130.

50. Ritcey, G.M.; Hayward, N.L.; Salinovich, T. The Recovery of Nickel and Cobalt from Lateritic Ores. Australian Patent AU-B-40890, 18 July 1996.

51. Xu, D.; Liu, L.X.; Quast, K.; Addai-Mensah, J.; Robinson, D.J. Effect of nickel laterite agglomerate properties on their leaching performance. Adv. Powder Technol. 2013, 24, 750-756. [CrossRef]

52. McDonald, R.G.; Whittington, B.I. Atmospheric acid leaching of nickel laterites review. Part I. Sulphuric acid technologies. Hydrometallurgy 2008, 91, 35-55. [CrossRef]

53. MacCarthy, J.; Nosrati, A.; Skinner, W.; Addai-Mensah, J. Temperature Influence of Atmospheric Acid Leaching Behaviour of Saprolitic Nickel Laterite Ore. In Proceedings of the Chemeca 2013: Challenging Tomorrow, Brisbane, Australia, 29 September-2 October 2013; Wang, L., Ed.; Engineers Australia: Brisbane, Australia, 2013; pp. 439-443.

54. Hunter, H.M.A.; Herrington, R.J.; Oxley, E.A. Examining Ni-laterite leach mineralogy \& chemistryA holistic multi-scale approach. Miner. Eng. 2013, 54, 100-119.

55. Komnitsas, K.; Zaharaki, D. Geopolymerisation: A review and prospects for the minerals industry. Miner. Eng. 2007, 20, 1261-1277. [CrossRef]

56. Zaharaki, D.; Komnitsas, K. Valorization of construction and demolition (C\&D) and industrial wastes through alkali activation. Constr. Build. Mater. 2016, 121, 686-693.

(C) 2018 by the authors. Licensee MDPI, Basel, Switzerland. This article is an open access article distributed under the terms and conditions of the Creative Commons Attribution (CC BY) license (http:/ / creativecommons.org/licenses/by/4.0/). 